\title{
ECOlogical ConneCTIVITY Protection ACCORDING TO THE EUROPEAN UNION AND POLISH LAW
}

\author{
KAMILA SOBIERAJ* \\ PIOTR ZACHARCZUK**
}

\section{INTRODUCTION}

Assuring ecological connectivity is especially significant in the cases of species having high spatial requirements. ${ }^{1}$ For example, the research into the lives of wolves has shown that the young wolves leaving the pack migrate in search of partners for breeding and to find unsettled territories. About 6 per cent of young wolves migrate within the distance of up to $100 \mathrm{~km}$, and almost 95 per cent within the range of up to $300 \mathrm{~km}$ from their native pack's habitat ${ }^{2}$. On the other hand, assuming a relatively dense lynx population, amounting to about 1.5 lynx per $100 \mathrm{~km}^{2}, 50$ lynxes need about $3500 \mathrm{~km}^{2}$ of regular habitat. Because of the landscape fragmentation and the habitats destruction, in Europe there are very few appropriate areas of the size ${ }^{3}$.

One of the biggest threats to the survival of many animal' species is the progressive fragmentation of their natural habitats by diverse human activity resulting in the emergence of an ecological connectivity problem ${ }^{4}$.

\footnotetext{
DOI: $10.1515 /$ wrlae-2015-0040

* PhD in Law, Assistant Professor at the Department of Environmental Management Law, the Faculty of Law and Administration, The John Paul II Catholic University of Lublin, Spokojna Street 1, 20 - 074 Lublin, Poland, e-mail: sobieraj@kul.pl.

**PhD in Law, Assistant Professor at the Department of Public Management and Administrative Law, the Faculty of Law and Administration, The John Paul II Catholic University of Lublin, Spokojna Street 1, 20 - 074 Lublin, Poland, e-mail: zacharczuk@kul.pl. ${ }^{1}$ Włodzimierz Jędrzejewski, Sabina Nowak, Rafał Kurek, Robert W. Mysłajek, Krystyna Stachura, Bernadetta Zawadzka, Marcin Pchałek, Animals and Roads. Methods of mitigating the negative impacts of Roads on wildlife (Polish Academy of Science 2009) 11.

${ }^{2}$ Henryk Okarma, Roman Gula, Piotr Brewczyński, Krajowa strategia wilka warunkująca trwałość gatunku w Polsce (Nature Conservation Institute 2011) 11.

${ }^{3}$ Gabriel Schwaderer, 'Znaczenie sieci ekologicznych dla dużych ssaków drapieżnych w Europie' in Włodzimierz Jędrzejewski, Dorota Ławreszuk (eds), Ochrona łączności ekologicznej w Polsce (Polish Academy of Science 2009) 62.

${ }^{4}$ Bogumiła Jędrzejewska, Włodzimierz Jędrzejewski, 'Wpływ fragmentacji środowiska na populacje zwierząt i ochrona łączności ekologicznej’ in Jędrzejewski, Ławreszuk (eds), Ochrona łączności (n 3) 13-14.
} 
The existence of species requiring greater living space and freedom of movement in fragmented environments is possible only due to the presence of wildlife corridors, which ensure ecological connectivity between suitable habitats and thus provide shelter, access to food and, above all, the genetic diversity essential for animal populations. The absence of wildlife corridors is, in turn, the major factor that limits the natural range of wild species.

Maintaining ecological connectivity is at present one of the biggest challenges that the modern nature conservation in European Union (EU) Member States faces, as one of the elements of European integration is creating a powerful transport infrastructure network connecting, first of all, the EU Member States. Therefore, the European Commission adopted so called Trans-European Network Strategy. The network was supposed to play the key role in the integration of European internal markets by making the flow of passengers and goods passable (providing a free flow of people and goods). On the other hand, however, implementation of the Trans-European Network Strategy influences the wildlife flora and fauna in Europe in a very adverse manner. Very frequently transport infrastructure, especially the enclosed roads, creates barriers that make it difficult for many species to migrate and spread. The main reason behind this is the intensive economic development which entails development of forest and agricultural lands, including the development of transportation infrastructure (roads and railways) with the simultaneous lack of comprehensive, countrywide implementation of ecological connectivity protection programmes designed to prevent or moderate landscape fragmentation. ${ }^{5}$

The main aim of this article is to provide an overview and discussion of EU and domestic Polish legislation and policy concerning ecological connectivity conservation at both the national and also at the international level. In this publication, the authors aim at presenting the essential legal acts imposing upon the EU and Member States the obligation of conservation of ecological connectivity among the staying places of large migratory predators, which is necessary to assure the proper condition of those populations. This article also considers the issue of the Polish system of legal regulations aiming at implementation of the international and EU obligations. The authors also intend to identify and systematize some barriers, which appeared in the practice of applying the regulations regarding protection of the ecological corridors. Elimination of those barriers may increase the efficiency and effectiveness of the protection system. "The source" (beginning) of the protection problems are very often ineffective legal regulations at the international and EU levels (there is often a necessity to "precisely interpret" the obligation to establish and protect the ecological corridors. The regulations do not create a complex system of protection, but they are "independent", "scattered" regulations), thus it can hardly be expected that the national law or instruments might bring the anticipated effects. The factor which considerably reduces the effects of implemented protection for many predators is the absence of effective implementation of proper instruments for protection of ecological connectivity between the

\footnotetext{
${ }^{5}$ Widely discussed in: European Environment Agency \& Swiss Federal Office for the Environment, Landscape fragmentation in Europe (Publications Office of the EU 2011).
} 
staying places of many large predators at the national level, and also a lack of creation and implementation regarding the complex European system of ecological corridors. In view of the fact that, for example, eight out of ten European wolf populations span the area of two or more countries ${ }^{6}$, ecological corridors are needed not only at the national but also at the European range. As Poland is not capable of overcoming the last barrier independently; international cooperation is necessary (thus, publication of this article at the international forum becomes also significant).

The issues of ecological connectivity (establishing ecological corridors) are often discussed in literature, but by representatives of the natural and social sciences. Frequently, the concepts of ecological connectivity protection are presented (creating migration corridors) of nationwide range (including particular EU Member States), legal aspects of the issue are, however, often ignored ${ }^{7}$. However, the absence of (proper) legal authorization of many programs (instruments) of protection, and the absence of legal regulations for financing the establishing and functioning of European ecological corridors is the reason for a failure to implement the good concepts of naturalists.

\section{Ecological Connectivity Protection according to EUROPEAN UNION LAW}

With ever increasing amounts of land being claimed by humans for agricultural purposes and urban development, the area of habitats most valuable to wild fauna and flora is being severely limited, while existing habitats are being divided into small, isolated patches. ${ }^{8}$ Among the so called large predators, wolves, lynxes and bears are included in Poland by biologists in the group of those subject to particular danger of roads impact, in view of high spatial requirements and long distance movement ${ }^{9}$. Of course, it must be

\footnotetext{
${ }^{6}$ Table 4 'Overview of the population structure of wolves (Canis lupus) in Europe' in John Linnell, Valeria Salvatori, Luigi Boitani, Guidelines for population level management plans for large carnivores in Europe. A Large Carnivore Initiative for Europe report prepared for the European Commission (Large Carnivore Initiative for Europe 2008) 48; Table S9 'Wolf population names, countries and literature references' in Guillaume Chapron et al., 'Recovery of large carnivores in Europe's modern human-dominated landscapes' (2014) 346 Science 15-17, supplementary materials, 26-27.

${ }^{7}$ However there are few publications which rise the issue in general way, e.g. Barbara Lausche, David Farrier, Jonathan Verschuuren, Antonio G. M. La Viña, Arie Trouwborst, Charles-Hubert Born, Lawrence Aug, 'The Legal Aspects of Connectivity Conservation - A Concept Paper' (2013) 85 IUCN Environmental Policy and Law Paper 1; Arie Trouwborst, 'The Habitats Directive and Climate Change: Is the Law Climate Proof?' in Charles-Hubert Born, An Cliquet, Hendrik Schoukens, Delphine Misonne and Geert Van Hooric (eds), The Habitats Directive in its EU environmental law context: European nature's best hope? (Routledge 2014) 303-324; Arie Trouwborst, 'Transboundary Wildlife Conservation in a Changing Climate: Adaptation of the Bonn Convention on Migratory Species and its Daughter Instruments to Climate Change' (2012) 4 Diversity 258-300.

${ }^{8}$ Schwaderer (n 3) 62; Robert W. Mysłajek, Marcin Miłosz-Cielma, Dorota Lawreszczuk, Włodzimierz Jędrzejewski, Sabina Nowak, Rafał Kurek, 'Budowa przejść dla zwierząt jako instrument ochrony łączności ekologicznej - zrealizowane i projektowane przejścia dla zwierząt w Polsce' in Jędrzejewski, Ławreszuk (eds), Ochrona łączności (n 3) 192.

9 Jędrzejewski et al. (n 1) 14; Bjørn Iuell, Hans Bekker, Ruud Cuperus, Jiri Defek, Gary Fry, Claire Hicks, Vaclav Hlavac, Verena Keller, Carme Rosell, Tony Sangwine, Niels Tørsløv,
} 
admitted that the movement of lynxes and bears is strictly related with existence of ecological corridors. However, in case of wolves, there are individuals able to cover little deforested areas and overcome some infrastructural obstacles, including dual carriageways. However, generally, the lack of proper ecological connectivity limits wolves' genetic replacement; however roads not only limit wolves' genetic replacement but also influence the death rate of wolves in those states. Both in Poland and Europe, the major factor affecting the natural range of wolves is (illegal) killing by humans. However, in some European countries (especially in Poland ${ }^{10}$ and Germany ${ }^{11}$, but also in Serbia ${ }^{12}$ and Romania ${ }^{13}$ ) the lack of proper ecological connectivity is considered to be (in fact not the most significant) an important factor influencing the wolf population.

According to the tests presented by the Polish biologists, the Polish wolf population is highly disjointed, and its particular parts number few individuals, and thus they are particularly exposed to extinction. ${ }^{14}$ Considering a lack of connections with other populations and no regular arrival of new individuals, even relatively few cases of death (e.g. because of poaching) may lead to disappearance of the local population. Maintaining connectivity between wolves population segments (which is still weak) is considered to be an important factor in wolf conservation, especially in Poland and Germany ${ }^{15}$. It is emphasized in the literature that for wolves, genetic diversity in Germany and western Poland it is necessary to define and protect ecological corridors in both countries. ${ }^{16}$ It must also be added that the

\footnotetext{
Barbara le Marie Wandall (eds), COST 341 - Habitat Fragmentation due to Transportation Infrastructure. Wildlife and Traffic - a European Handbook for Identifying Conflicts and Designing Solutions (European Co-operation in the Field of Scientific and Technical Research 2003). Wolf is one of the animals on which the report focuses with regard to ecological corridors construction.

10 Włodzimierz Jędrzejewski, Magdalena Niedziałkowska, Sabina Nowak, Bogusława Jędrzejewska, 'Habitat variables associated with Wolf (Canis lapus) distribution and abundance in northern Poland' (2004) 10 (3) Diversity and distributions (A Journal of Conservation Biogeography) 225-233; Włodzimierz Jędrzejewski, Magdalena Niedziałkowska, Sylwia Nowak, Bogusława Jędrzejewska, 'Habitat selection by volves Canis lapus in the uplanda and mountains of southern Poland' (2005) 50 Acta Theriologica 417-428; Marcin Popiołek, Justyna Szczęsna, Sabina Nowak, Robert W. Mysłajek, 'Helminth infections in faecal Samales of wolves Canis lapus L. from the western Beskid Mountains in southern Poland' (2007) 81 Journal of Helminthology 339-344;

Maren Huck, Włodzimierz Jędrzejewski, Tomasz Borowski, Małgorzata Miłosz-Cielma, Krzysztof Smidth, Bogumiła Jędrzejewska, Sabina Nowak, Robert W. Misłajek, 'Habitat suitability, corridors, dispersal barriers for large carnivores in Poland' (2010) 55 Acta Theriologica 177-192; Maren Huck, Wodzimierz Jędrzejewski, Tomasz Borowski, Bogumiła Jędrzejewska, Sylwia Nowak, Robert W. Misłajek, 'Analyses of the least cost patos for determining effects of habitat types on landscape permeability: wolves in Poland' (2011) 56 Acta Theriological 91-101.

${ }^{11}$ Petra Kaczensky et al., Status, Management and Distribution of Large Carnivores-Bear, Lynx, Wolf and Wolverine - in Europe (Report to the European Commission, Part 2, Brussels 2013) 148.

12 ibid. 182.

13 ibid. 178.

${ }^{14}$ Jędrzejewski et al.(n 1) 15.

${ }^{15}$ Kaczensky et al. (n 11) 147.

${ }^{16}$ Reinhardt, Kluth, Nowak, Mysłajek (n 8) 87.
} 
Polish ecological corridors are also an important link in the ecological connectivity on the European scale. Owing to the wilderness of the northern Poland and a network of corridors, the connectivity of the eastern European natural habitats may be extended as far as the western borders of Poland and eastern Germany. It would make migrations of fauna at the continental scale possible, as well as enable the wider recolonization of the western Poland and other European states ${ }^{17}$.

A few international conventions may be listed here wherein the object of regulations is, indirectly or at least directly, the issue of ecological connectivity protection ${ }^{18}$. A part of those international law acts have been ratified by EU and thus they have also become a part of the EU law. In majority, those agreements contain very generally formulated obligations of the states-parties and do not qualify to be applied directly. Although they influence the form of the states-parties regulations, their real effectiveness depends on the way of their implementation into the national law (which, in many cases of the Member States, e.g. in Poland, raises many objections).

At the international law level, the provisions of the Convention on European Wildlife and Natural Habitats Conservation concluded in Bern on 19 September $1979^{19}$ (hereinafter 'the Bern Convention') are also significant from the perspective of wildlife corridor protection. In 1982, the Bern Convention was ratified by the EU. According to the provisions of Article 4 of the Convention, the parties undertake to pay special attention to the protection of areas important for migratory species, which are properly situated on the migration routes and function as the areas of hibernation, relaxation, prey, breeding or shedding (item 3); and also to coordinate actions regarding the natural habitats conservation, if they are located in the border areas (item 4).

From the point of view of wild fauna migration corridors, attention must be paid also to the convention on migratory wild fauna species drawn up in the City of Bonn on 23 June $1979^{20}$ (the EU has been a party in this convention since 1983). According to the Act's provisions, the parties acknowledge the need to undertake individually, or in cooperation with other states of the migratory species zone, actions to avoid the endangering of any migratory species. What is significant is that the parties being so called zone states with respect to any of the migratory species listed in Attachment I, should undertake efforts in order to protect and, if possible and appropriate,

\footnotetext{
17 Jędrzejewski et al. (n 1) 26.

${ }^{18}$ Apart from the below mentioned international contracts, the following must be listed: Convention on Wetlands of International Importance Especially as Waterfowl Habitat drawn up in Ramsar on 02 February 1971 (Journal of Laws 1978, No. 7, item 24 as amended); Convention of Biological Diversity drawn up Rio de Janeiro on 05 June 1992 ( Journal of Laws 2002, No. 184, item 1532); European Landscape Convention, drawn up in Florence on 20 October 2000 (Journal of Laws 2006, No. 14, item 98); Framework Convention on the Protection and Sustained Development of the Carpathians, drawn up in Kiev on 22 May 2003 ( Journal of Laws 2007, No. 96, item 634 as supplemented); The Convention on the Protection of Marine Environment of the Baltic Sea, drawn up in Helsinki on 09 April 1992 (Journal of Laws 2000, No. 28, item 346). Some of the international contracts are widely discussed in Alexander Gillespis, Protected Areas and International Environmental Law (Collection 2007) 7-26.

${ }^{19}$ Convention on the Conservation of European Wildlife and Natural Habitats (Journal of Laws 1996, No. 58, item 263).

${ }^{20}$ Journal of Laws 2003, No. 2, item 17, see art. 2 and 3.
} 
restore the habitats of any of the species, whose reconstruction is necessary to prevent the threat of its extinction, as well as to prevent, eliminate, balance or minimize an adverse impact of the actions or obstacles considerably hampering or making the species migration impossible.

On the other hand, at the level of EU law within wildlife migration corridors protection, Acts concerning the environmental impact assessment require paying attention to (i.e. The European Parliament and Council Directive 2001/42/EC dated 27 June 2001 on assessment of the impact of some plans and programs upon the environment ${ }^{21}$ and The European Parliament and Council Directive 2011/92/EU dated 13 December 2011 regarding the assessment of environmental impact exerted by some public and private undertakings ${ }^{22}$ ), and also with respect to nature conservation (Directive 92/43/EEC of 1992 on Natural Habitats and Wild Fauna and Flora Conservation $^{23}$ - further referred to as the Habitats Directive and also The European Parliament and Council Directive 2009/147/EC dated 30 November 2009 on The Conservation of Wild Birds ${ }^{24}$ - further referred to as the Birds Directive) ${ }^{25}$.

Although in the Habitats Directive there are no direct references to the legal protection of ecological corridors, it may be stated those are the areas whose role is 'contributing to maintenance or restoration of the type of natural habitat referred to in Annex I or a species referred to in Annex II, in the proper state of conservation and/or contributing considerably to maintenance of biodiversity within a region or biogeographic regions concerned' (Article 1 let. k). The ecological corridors linking The Natura 2000 network areas play a significant role in the objectives of The Natura 2000 network coherence. In the European legislation and judicature of the EU Court of Justice, however, there is no clear definition of "the network coherence" (which may negatively impact on the effectiveness of the ecological corridors legal protection).

As an example of the EU legal standards imposing (indirectly) the obligation to establish and protect ecological corridors, we must indicate first of all the provisions of Article 3 item 3 of the habitats directive, including a requirement of making endeavours by the Member States to improve the ecological coherence of the Natura 2000 network, by maintenance, and where appropriate developing the features of the landscape which are of major importance for the wild fauna and flora'. The provisions of Article 10 of The Habitats Directive commit the Member States to make all endeavours in their spatial development plans and development policies - where they consider it necessary to encourage the maintenance of the features of landscape of considerable importance for the wild fauna and flora. Besides, a recommendation follows from Article 10 of The Habitats Directive, aiming at stressing the importance of the need for protection of those nature elements, which due to their linear or continued structure (for example rivers and their banks or traditional systems of areas borders designating) or performed

${ }^{21}$ [2001] OJ L 197/30.

22 [2012] OJ L 26/1.

${ }^{23}$ [1992] OJ L 206/7.

24 [2010] OJ L 20/7.

25 Marcin Pchałek, 'Prawne aspekty ochrony zwierząt przed wpływem infrastruktury drogowej i kolejowej’ in Jędrzejewski, Ławreszuk (eds), Ochrona łączności (n 3) 261-262. 
function of output expansion areas (for example ponds or little forests), are very important for the migration, spreading and genetic replacement of wild species $^{26}$. It follows from the above provisions, however, that the Member States have no obligation to provide support in maintaining ecological connectivity, but only to make endeavours towards this objective.

The obligation of ecological corridors protection may also be related to (there are no direct references here to the legal protection of ecological corridors) Article 2 of The Wild Birds Conservation Directive, which orders the Member States to take all necessary measures in order to maintain the wild birds population at the level, which 'corresponds in particular to ecological, scientific and cultural requirements, while taking account of the economic and recreational requirements or in order to adapt the population of the species to that level'. Article 3 item 2 of The Wild Birds Conservation Directive lists among those measures '(...) upkeep and management, according to ecological needs of natural habitats inside and outside protected zones', which is also related to conservation obligations with respect to ecological corridors. Moreover, in the judicature of the EU Court of Justice it has been repeatedly pointed out that providing preventive protection may require undertaking proper measures also as regards spaces located outside the areas of the network but having an impact upon its coherence - such as e.g. the migration corridors ${ }^{27}$.

It must be pointed out that the system of area conservation referred to in The Habitats Directive is not sufficiently extensive to ensure effective protection of ecological connectivity as such, similarly the regulations included in The Birds Directive shall not guarantee a full ecological protection as such and similarly The Wild Birds Conservation Directive will not guarantee full protection of all ecological corridors. The protection will be limited exclusively to ecological corridors of the species included in the Natura 2000 network, and also only in the range within which impact upon the corridors may have a considerable negative impact upon the integrity of an area and the network coherence. The protection will not refer to ecological corridors that have not been formally included in the Natura 2000 network (for example as a result of improper implementation of the directives) and which do not contribute to the upkeep of natural connectivity between the Natura 2000 network areas, among others areas of natural value.

Despite the regulations being adopted at the international and EU level, the protection of ecological connectivity (the creation of wildlife corridors) poses a considerable practical problem in European countries. Western Europe, in particular, is struggling with a high degree of landscape fragmentation. For example in Germany, it became one of the reasons for the disappearance of the species which require adequate space to satisfy their essential needs, including the wolf. ${ }^{28}$ With $1.9 \mathrm{~km} / \mathrm{km}^{2}$, Germany has the

\footnotetext{
${ }^{26}$ Marcin Pchałek, Mariusz Kistowski, Natura 2000 w planowaniu przestrzennym - rola korytarzy ekologicznych (Ministry of Environmantal Law, Warsaw 2009) 36.

${ }^{27}$ E.g. Judgment of the Court (Second Chamber) of 20 October 2005, C-6/04 and Judgment of the Court (Second Chamber) of 13 December 2007, C-418/04.

${ }^{28}$ Ilka Reinhardt, Gesa Kluth, Sabina Nowak and Robert W. Mysłajek, A review of wolf management in Poland and Germany with recommendations for future transboundary collaboration (Federal Agency for Nature Conservation 2013) 68.
} 
highest road density in Europe ${ }^{29}$. Unfortunately, the geographical scope of this problem is also increasing in the countries of central and Eastern Europe, including Poland.

Additionally, it must be pointed out that effectiveness of The Habitats and The Birds Directives (thus also the regulations on the grounds of which we may conclude the obligation of establishment and legal protection of the ecological corridors) has been decreased by the fact that many Member States have evaded the designation of areas as the Birds Conservation Special Areas or Habitats Conservation Special Areas although they met the natural criteria outlined in the Directives. Countries such as France, the Netherlands, Sweden or Finland encountered conflicts with the Commission in that respect. They had to verify in plus their initial projects, some of the disputes were decided at the EU Court of Justice. The most significant conflict in that respect has been, however, the dispute between Russia and Poland pending since 2004. In the dispute the Commission has been "supported" by independent experts and ecological organizations (mainly from Poland), which have been sending it so called shadow list, i.e. a much wider list of protected areas than the one included in the government's projects. At present, the differences of opinions between the Commission and Poland are relatively insignificant, but it still cannot be considered that Poland has fully implemented the obligations related to establishing and functioning of the Natura 2000 network.

Furthermore, the international and EU regulations related to the legal protection of ecological connectivity are not accompanied by the process of applying complex instruments contributing to their implementation. Many concepts of ecological connectivity (establishing the migration corridors) of different range have appeared: nationwide (comprising particular EU Member States), regional, but also European. Among the European ecological networks, the most important are: The Natura 2000 European ecological network and The ECONET European ecological network (the ecological corridors, apart from the nodal areas are the key elements of The ECONET). However, the scope of those concepts implementation (of different range) leaves much to be desired. The way of ecological connectivity conservation programs' implementation is not consolidated. Among the Member States are, admittedly, those which have implemented the nationwide programs of ecological connectivity, but there are many which have implemented regulations aimed at preventing or buffering landscape fragmentation without a complete, coherent concept ${ }^{30}$.

In many countries implementing the program of restoring ecological connectivity has been (for many years) at the conceptual stage. These programs in the majority of cases have not found their legal authorization, so it is hard to expect implementation of ecological corridors of the systems presented therein. A similar situation concerns implementation of the ECONET network in particular Member States. For example the ECONETPoland network created in the 1990s has no legal status; it is also too general

\footnotetext{
${ }^{29}$ Source: <<www.bfn.de >> accessed 27 June 2017,

30 Elke Spindler, Völk Reiss-Enz, 'Defragmentation in Austria', lecture delivered at the conference 'Defragmentation concepts in Central Europe' in Vilm, Germany, 14-18 September 2008.
} 
and includes barriers restricting the migration of organisms in the ecological corridors. Moreover, more than 15 years have passed since the study was carried out. During that time a considerable growth of communication and technical infrastructure has occurred, as well as the development of a part of the areas within the designated corridors. Only by creating a consolidated European ecological network and providing it with a legal status will an effective protection of the ecological corridors ${ }^{31}$ be achieved. The protection of ecological corridors may only be effective if it comprises the whole network of corridors, preferably on an international scale $\mathrm{s}^{32}$.

\section{Ecological Connectivity Protection ACCORding to POLISH LAW}

In the Polish legal system, ecological connectivity is protected under many regulations on both the national and the regional level. The planning and development Act of 27 March 2003 determines the general principles for environmental protection and spatial planning procedures on national, regional, and local levels. ${ }^{33}$ The planning procedures, and later building procedures, are governed by the provisions of the Act of 3 October 2008 on publishing information about the environment and its conservation, public participation in the environmental protection, and environmental impact assessment. ${ }^{34}$ The Nature Conservation Act (hereinafter ' $\left.N C A '\right)^{35}$ determines, inter alia, conditions resulting from species protection and maintaining conservation areas. The Act of 27 April 2001 Environmental Protection Law, ${ }^{36}$ in turn determines, inter alia, rules for environment protection in spatial planning and building. This environmental protection system is disrupted by provisions of the so-called special acts, which preclude the application of the Act on spatial planning and development, especially the Act of 10 April 2003 on special terms for the preparation and implementation of public road investments. ${ }^{37}$ In practice, such legal situations may lead to public roads being built independently from the evaluations of strategic spatial planning plans, which may be significant for the identification of cumulative impacts on wildlife corridors. ${ }^{38}$ It must be noted that it is roads which are becoming greater and greater barriers to animal migration. The increasingly heavy traffic, together with the modernisation of old roads and the building of new roads, are currently causing many such negative effects. ${ }^{39}$ In Poland, this problem became serious after Poland's accession to the EU on

\footnotetext{
${ }^{31}$ From the National Spatial Development Concept 2030 it appears that in 2010 only slightly over 26 per cent of Poland's area had an obligatory local plan.

${ }^{32}$ Widely discussed in M. Bloemmen, Theo van der Slusis, European corridors - example studies for the Pan-European Ecological Network, Alterra, Wageningen 2004, http://www2.alterra.wur.nl/Webdocs/PDFFiles/Alterrarapporten/AlterraRapport1087.pdf, accessed 27 June 2017.

${ }^{33}$ Consolidated text Journal of Laws 2015, item 199 as amended.

${ }^{34}$ Consolidated text Journal of Laws 2013, item 1235 as amended.

35 Journal of Laws 2015, item 1651 as amended.

${ }^{36}$ Consolidated text Journal of Laws 2013, item 1232 as amended.

${ }^{37}$ Consolidated text Journal of Laws 2015, item 2031 as amended.

${ }^{38}$ Pchałek (n 25) 261-262.

39 Jędrzejewski et al. (n 1) 17.
} 
1 May 2004, when there was a rapid increase in infrastructure projects, including road development.

With legal instruments provided by the spatial planning system not applicable to investments in public roads, the possibility of migration must be ensured by designation and protection of wildlife corridors under provisions of the NCA. The acts of designating wildlife corridors and granting them protected area status will then have to be taken into consideration in the strategic environmental assessment of plans for road and rail infrastructure and the environmental assessment of road and rail infrastructure projects.

The NCA contains the legal definition of the term "wildlife corridor" $^{40}$. According to NCA, wildlife corridors are not separate forms of nature conservation. Only those parts of wildlife corridors which territorially overlap with areal forms of nature conservation listed in Article 6 item 1 of the NCA, are protected as areal forms of nature conservation. Amongst areal forms of nature conservation, the NCA attributes the functions related with wildlife corridors protection directly only to areas of protected landscape ${ }^{41}$. Areas of protected landscape may act as wildlife corridors. ${ }^{42}$ However, in practice, protected landscape does not provide sufficient protection, as it is the weakest form of environmental protection. The issue of wildlife corridors within protected landscape areas is often disregarded. What is more, in the present legal situation, maintaining a protected landscape area is a very conservative form of protection and only implies some restrictions with little actual significance. ${ }^{43}$ Therefore, it would be advisable to introduce changes in legislation that would provide the NCA with a new form of environment protection, "wildlife corridor", or modify the existing legislation on the functioning of areas of protected landscape. It is necessary that the changes in legislation on protecting ecological corridors include the obligation to take concrete action by the competent authorities, which may take the form of, inter alia, increasing woodland areas and the construction of animal crossings (viaducts or tunnels) on new and existing expressways and as well as roads with a high traffic volume.

In addition to investments in public roads, other projects carried out within wildlife corridors, to which the regulations of the Planning and Development Act are already applied, may also impede wolf migration. This means that projects carried out within areas covered by local spatial development plans must be in accordance with those plans. A local spatial development plan must state, inter alia: the future use of the land and delimitation lines for areas of various future purposes; protective measures for the environment, nature, and cultural landscape; boundary lines and ways of managing protected areas and objects set by separate provisions; and special land use conditions and limitations on its use, including construction bans. This implies that the existing wildlife corridors should be taken into

\footnotetext{
${ }^{40}$ According to Article 5 section 2 of the NCA it is an area that makes it possible for plants, animals or fungi to migrate.

${ }^{41}$ Marcin Pchałek, Paulina Kupczyk, Piotr Matyjasiak, Adam Juchnik, Efektywność ochrony korytarzy ekologicznych. Koncepcja zmian legislacyjnych (WWF Poland, Warsaw 2011) 6465 .

${ }^{42}$ Art. 23 item 1 of the NCA.

${ }^{43}$ Art. 24 of the NCA
} 
consideration in the local plan. In practice, restrictions in the use of land comprising wildlife corridors, construction bans in particular, are rarely introduced. In the part devoted to the development of spatial structures supporting the achievement and preservation of Poland's high-quality natural environment and landscape, the National Spatial Development Concept 2030 acknowledges a prevailing problem concerning wildlife corridors. ${ }^{44}$

It states that the wildlife corridors which run across Poland are not, regardless of their status within national and continental nature systems, precisely defined by law. Also, they lack instruments that would allow for definition and protection of their functions in spatial development planning. Despite many changes in the protected areas system, there are no sufficient legal bases for the protection of wildlife corridors, the establishment of their permanent network, and the shaping of spatial structures that would support the functions of rural areas. These enable the preservation of cultural space and the good ecological status of the existing nature resources. For that reason, the National Spatial Development Concept 2030 emphasized that the national spatial planning policy needs to, in a more decisive manner, counteract the process of habitat fragmentation and support the creation of solutions allowing for optimum ecological connections that would foster migration and secure the essential living needs of protected species. In order to preserve the potential of Poland's natural environment, the management of planned functional and landscape structures demands the creation of longterm strategies to reconcile the objectives of technical environment and landscape protection, and those of settlement, transport, and tourism in order to mitigate and solve possible conflicts. This calls for actions against natural landscape defragmentation. The local spatial development plan establishes the purpose of a given site, the location of public purpose investments on site, the specification of development, and land development conditions. If there is no such plan, an administrative decision concerning the manner and conditions of spatial development is issued. An administrative decision on the manner and conditions of spatial development may not be issued due to the presence of an existing wildlife corridor only when the investment plan contradicts provisions of the NCA or regulations based on the NCA pertaining to protected areas, and in particular to areas of protected landscape. However, due to the fact that there are no sufficient legal bases for the protection of wildlife corridors in the NCA, decisions on the location of public purpose investments or decisions on the conditions of spatial development are hardly ever negative. In connection with the continued poor coverage of the country's territory by valid local spatial development plans, the protection of ecological connectivity between many large predators' habitats is illusory. Planning and implementing the protection of many large predators' wildlife corridors in Poland, although very important, is exceedingly difficult due to the present legal conditioning.

\section{CONCLUSIONS AND RECOMMENDATIONS}

\footnotetext{
${ }^{44}$ Appendix to the Council of Ministers Resolution of 13 December 2011 on National Spatial Management Concept 2030 (Official Journal of the Republic of Poland Polish Gazette 2012 item 252).
} 
In order to assure the survival of mammals of high dispersion reach, especially the big predatory mammals, it is especially important to assure, on a large scale, a continuity of the appropriate habitats. To maintain the proper population of fauna, which needs relevant space to meet its needs, it is necessary to establish a complex system of ecological connectivity among the staying places of those predators by establishing and protection of ecological corridors, including, obligatorily, those of pan-European (transborder) type. The system must also comprise taking up at the EU level, and consequently at the national level, coherent and interconnected protective actions, both with respect to planning, of legislative type, and also the executive ones. The undertaken actions must be regularly monitored and should a need arise - modified. A proper program for financing those actions should be also created. Such a joint undertaking, having an European dimension, will not only allow maintaining the proper number of large predators in Poland and other states of Central and Eastern Europe, which are considered to be one of the most important regions for big mammals existence in Europe. It will also allow large predator migration to, and settlement in, Western Europe, a large part of which is deprived of those predators. It would be an instrument of EU obligations accomplishment with respect to joint actions and cooperation of the Member States regarding protection of many large predators' species in the border areas, which will contribute to assuring biodiversity by conservation of natural habitats and wild fauna in the European territory of the Member States.

A significant action from the point of planning is, first and foremost, designating and protecting a network of the European ecological corridors (establishing a European system of areas connected in ecological and physical ways, consisting of nodal areas, ecological corridors and buffer zones). The Natura 2000 network still does not sufficiently meet the requirements of the functional continuity of protected species. Similarly, The ECONET has not met the hopes related to its maintaining the expected level of biodiversity in the whole territory of Europe. Therefore, it is necessary to work out a more complex concept. On the other hand, at the level of each Member State, and also at the biogeographic region level, local strategies and protective actions plans for the ecological corridors ought to be established. The EU law should also impose the obligation of drawing up and implementing nationwide programs of ecological connectivity protection.

EU law should obligate the Member States to implement the national regulations concerning the habitat connectivity which predict the fauna protection on motorways and other types of roads. Those roads, according to the standards and safety requirements in force, need enclosing. This, on the other hand, means the roads are a complete barrier to migration of the large earthbound fauna. The Member States should be obliged to assess the functional level of the existing passages and construct new passages over the existing and newly built motorways in order to restore the ecological corridors of national and international significance. The required elements are the regulations containing guidelines detailing the way of marking and enclosing the roads, construction and maintenance of passages for the fauna, 
as well as the rules of their functionality control ${ }^{45}$.

Regarding, not only Poland, but the whole area of the EU, it is also necessary to regulate the financing of creating and functioning of the European ecological corridors. The system should include proper financial instruments enabling the taking of actions to actively protect the ecological corridors essential elements (based for example on afforestation according to the rules of infrastructural undertakings carried out according to similar principles as the infrastructural undertakings implemented through The Infrastructure and Environment Operational Program ${ }^{46}$ ), or conducting video surveillance.

\footnotetext{
45 Krzysztof Niedziałkowski, 'Wdrażanie systemu ochrony łączności ekologicznej na przykładzie wybranych krajów europejskich’ in Jędrzejewski, Ławreszuk (eds), Ochrona taczności (n 3) 33.

${ }^{46}$ LIFE Programme, in Poland' case, has not played significant role within ecological corridors afforestation. See Regulation (EU) No. 1293/2013 of the European Parliament and of the Council of 11 December 2013 on the establishment of a Programme for the Environment and Climate Action (LIFE) [2013] OJ L 347/185.
} 